\title{
Tyrosine requirement during the rapid catch-up growth phase of recovery from severe childhood undernutrition
}

\author{
Asha Badaloo $^{1 *}$, Jean W.-C. Hsu ${ }^{2}$, Carolyn Taylor-Bryan ${ }^{1}$, Marvin Reid ${ }^{1}$, Terrence Forrester ${ }^{1}$ \\ and Farook Jahoor ${ }^{2}$ \\ ${ }^{1}$ Tropical Metabolism Research Unit, University of the West Indies, Mona, Kingston 7, Jamaica \\ ${ }^{2}$ Department of Pediatrics, USDA/ARS Children's Nutrition Research Center, Baylor College of Medicine, 1100 Bates Street, \\ Houston, TX 77030-2600, USA
}

(Received 8 September 2009 - Revised 16 April 2010 - Accepted 19 April 2010 - First published online 16 June 2010)

The requirement for aromatic amino acids during the rapid catch-up in weight phase of recovery from severe childhood undernutrition (SCU) is not clearly established. As a first step, the present study aimed to estimate the tyrosine requirement of children with SCU during the catch-up growth phase of nutritional rehabilitation using a diet enriched in energy and proteins. Tyrosine requirement was calculated from the rate of excretion of ${ }^{13} \mathrm{CO}_{2}\left(\mathrm{~F}^{13} \mathrm{CO}_{2}\right)$ during $\left[{ }^{13} \mathrm{C}\right]$ phenylalanine infusion in thirteen children with SCU, five females and eight males, at about $19 \mathrm{~d}$ after admission when the subjects were considered to have entered their rapid catch-up growth phase and were consuming $627.3 \mathrm{~kJ}$ and about $3.5 \mathrm{~g}$ protein $/ \mathrm{kg}$ per $\mathrm{d}$. Measurements of $\mathrm{F}^{13} \mathrm{CO}_{2}$ during $\left[{ }^{13} \mathrm{C}\right]$ phenylalanine infusion were made on two separate days with a $1 \mathrm{~d}$ interval. Three measurements at tyrosine intakes of 48,71 and $95 \mathrm{mg} / \mathrm{kg}$ per d were performed on experimental day 1 and measurements at tyrosine intakes of 148,195 and $241 \mathrm{mg} / \mathrm{kg}$ per $\mathrm{d}$ were performed on experimental day 2 . An estimate of the mean requirement was derived by breakpoint analysis with a two-phase linear regression cross-over model. The breakpoint, which represents an estimate of the mean tyrosine requirement, is a value of $99 \mathrm{mg} / \mathrm{kg}$ per $\mathrm{d}$ when the children were growing at about $15 \mathrm{~g} / \mathrm{kg}$ per $\mathrm{d}$. The result indicates that the mean requirement for tyrosine during the catch-up growth phase of SCU is about $99 \mathrm{mg} / \mathrm{kg}$ per d under similar conditions to the present study.

Tyrosine requirement: Catch-up-growth: Childhood undernutrition

In severe childhood undernutrition (SCU) amino acids available for metabolic purposes may be in short supply because of the reduced protein intake associated with chronic food deprivation. In addition, because breakdown of body proteins is the major contributor to the overall flux of amino acids $^{(1)}$, our finding that whole-body protein breakdown rate is slower in children with SCU compared with the rate at recovery ${ }^{(2)}$ suggests a severe combined shortage in the availability of amino acids in children with SCU. Whereas such a reduction in availability will be especially true for the indispensable amino acids, supply of the dispensable amino acids also will be compromised unless there is an up-regulation of de novo synthesis. This may not be possible for a dispensable amino acid such as tyrosine whose precursor is the indispensable amino acid phenylalanine. Because tyrosine is the precursor of the neurotransmitters dopamine, noradrenaline and adrenaline and of the thyroid hormones and melanin, a shortage of tyrosine (or its precursor, phenylalanine) may be involved in the pathogenesis of the neurological and metabolic abnormalities and skin changes associated with SCU.

Once the acute problems of SCU have been treated, the goal is to hasten catch-up growth of the children to enable quick return to normal weight-for-height. Usually this is achieved using energy-dense diets, also enriched with proteins and other nutrients. Estimated requirements for proteins and amino acids during the rapid catch-up growth phase have been based on assumptions about the composition of tissue gain, the magnitude of the maintenance values for protein and energy, the efficiency of utilisation of dietary protein and energy and the efficiency of net protein and fat deposition $^{(3-5)}$. This factorial approach based only on tissue protein content does not account for restoration of other depleted proteins, such as plasma proteins, which happen to have a high content of the aromatic amino acids ${ }^{(6)}$. Hence, it is not known if the amount of aromatic amino acids supplied in the standard catch-up growth diet is sufficient to meet the demands of increased lean tissue and nutrient transport proteins syntheses and the synthesis of other aromatic amino acid-derived compounds during a period when growth rates may be ten times greater than normal ${ }^{(4)}$. At present, requirement for phenylalanine during the rapid catch-up growth phase is not known with certainty. A determination of phenylalanine requirement can only be made, however, during an adequate dietary intake of tyrosine. As a first step, the present study aimed to estimate the tyrosine requirement during the rapid catch-up growth phase of children admitted to hospital

Abbreviations: $\mathrm{F}^{13} \mathrm{CO}_{2}$, rate of excretion of ${ }^{13} \mathrm{CO}_{2}$; SCU, severe childhood undernutrition; TMRU, Tropical Metabolism Research Unit.

*Corresponding author: Dr Asha Badaloo, fax +1 876977 0632, email asha.badaloo@uwimona.edu.jm 
for treatment of severe undernutrition, using the indicator amino acid oxidation method described by Roberts et al. ${ }^{(7)}$.

\section{Subjects and methods Subjects}

The participants in the study were thirteen children (five females and eight males), who were admitted for treatment of SCU to the metabolic ward of the Tropical Metabolism Research Unit (TMRU) of the University of the West Indies. During hospitalisation, the children were managed according to a standard treatment protocol as previously described by us (for example, Jahoor et al. ${ }^{(2)}$ ). As shown in Table 1, the children were aged about 9 months and had a deficit in body weight-for-age of more than $20 \%$. The diagnosis of type of SCU, that is marasmus, kwashiorkor or marasmic kwashiorkor, was based on the Wellcome classification ${ }^{(8)}$. Of the children, nine were diagnosed with marasmus, two with kwashiorkor and two with marasmic kwashiorkor. At admission, all of the children had evidence of one or more infections, all were anaemic and six were hypoalbuminaemic.

The present study was conducted according to the guidelines laid down by the Declaration of Helsinki and all procedures involving subjects/patients were approved by the Medical Ethics Committee of the University Hospital of the West Indies and the Baylor Affiliates Review Board for Human Subject Research of Baylor College of Medicine. Written informed consent was obtained from at least one parent of each child enrolled.

\section{Study design}

Tyrosine requirement was measured at about $19 \mathrm{~d}$ after admission when the subjects were considered to be at the mid-point of their rapid catch-up growth phase and they were consuming $627.3 \mathrm{~kJ}$ and about $3.5 \mathrm{~g}$ protein $/ \mathrm{kg}$ per $\mathrm{d}$. At this time the subjects had lost all signs and symptoms of infection, those with kwashiorkor and marasmic kwashiorkor had lost their oedema and the children's weights were increasing rapidly (Table 1).

Table 1. Characteristics of thirteen children with severe childhood undernutrition at admission and at the time of their study $\dagger$

(Mean values with their standard errors)

\begin{tabular}{|c|c|c|c|c|}
\hline \multirow[b]{2}{*}{ Parameter } & \multicolumn{2}{|c|}{ Admission ( $n$ 13) } & \multicolumn{2}{|c|}{ Study (n 13) } \\
\hline & Mean & SE† & Mean & SE† \\
\hline Age (months) & $9 \cdot 2$ & $1 \cdot 1$ & $10 \cdot 2$ & $1 \cdot 1$ \\
\hline Weight $(\mathrm{kg})$ & $4 \cdot 7$ & 0.3 & $5 \cdot 2^{*}$ & 0.35 \\
\hline Length (cm) & 61 & 1.4 & $61 \cdot 6^{\star}$ & 1.5 \\
\hline Weight-for-age (\%) & $55 \cdot 5$ & $3 \cdot 0$ & $57 \cdot 25^{\star}$ & $2 \cdot 3$ \\
\hline Weight-for-length (\%) & $77 \cdot 8$ & 1.9 & $84 \cdot 7^{\star}$ & $2 \cdot 4$ \\
\hline Temperature $\left({ }^{\circ} \mathrm{C}\right)$ & $37 \cdot 3$ & 0.2 & $36 \cdot 7^{\star}$ & 0.1 \\
\hline $\mathrm{Hb}(\mathrm{g} / \mathrm{l})$ & $86 \cdot 5$ & $3 \cdot 2$ & 86 & $2 \cdot 2$ \\
\hline Albumin (g/l) & $34 \cdot 7$ & $2 \cdot 3$ & $41 \cdot 1^{*}$ & 1.45 \\
\hline Weight gain (g/kg per d) & - & - & 15 & 1.5 \\
\hline
\end{tabular}

* Mean value was significantly different from that at admission $(P<0.05$; two-sided paired $t$ test).

†Of the subjects, nine had marasmus, two kwashiorkor and two marasmic kwashiorkor according to the Wellcome classification ${ }^{(8)}$

$\ddagger \mathrm{df}=12$.
A constant infusion of $\left[1-{ }^{13} \mathrm{C}\right]$ phenylalanine was used to determine tyrosine requirement.

During the catch-up growth phase of our treatment protocol a diet high in energy and other nutrients is usually fed every $3-4 \mathrm{~h}$ as dictated by the child's appetite and documented intakes are usually in the range $627 \cdot 3-752.8 \mathrm{~kJ}$ and approximately $2 \cdot 3-4.2 \mathrm{~g}$ protein $/ \mathrm{kg}$ per $\mathrm{d}$. The rate of excretion of ${ }^{13} \mathrm{CO}_{2}\left(\mathrm{~F}{ }^{13} \mathrm{CO}_{2}\right)$ from $\left[{ }^{13} \mathrm{C}\right]$ phenylalanine oxidation was measured during a constant intragastric infusion of this highenergy feed at a rate that provided $627.3 \mathrm{~kJ}$ and $3.5 \mathrm{~g}$ protein $/ \mathrm{kg}$ per $\mathrm{d}$. On attaining this rate of intake, the rate of feeding was maintained for $2 \mathrm{~d}$ before taking the measurements. The feed was made from a commercial milk powder (Bionan; Nestlé SA, Vevey, Switzerland), glucose and a vegetable oil, so that $1 \mathrm{~g}$ protein $/ \mathrm{kg}$ per $\mathrm{d}$ was provided as milk protein and $2.5 \mathrm{~g} / \mathrm{kg}$ per $\mathrm{d}$ as a mixture of nineteen amino acids prepared to reflect the amino acid composition of Bionan milk protein. This allowed us to vary the tyrosine intakes during the $\left[{ }^{13} \mathrm{C}\right]$ phenylalanine infusion period. The dietary phenylalanine intake was fixed at $140 \mathrm{mg} / \mathrm{kg}$ per d (amount contained in $3.5 \mathrm{~g}$ Bionan milk protein) during the experimental period. We aimed to make measurements at tyrosine intakes of $47 \cdot 3$ (amount supplied by the $1 \mathrm{~g}$ Bionan milk protein), 71.6, 96.7, 148, 195 and $242 \mathrm{mg} / \mathrm{kg}$ per $\mathrm{d}$. These are the amounts of tyrosine that would have been supplied by Bionan milk protein intakes of 1.0, 1.5, 2.0, 3.0, 4.5 and $5 \mathrm{~g} / \mathrm{kg}$ per d. However, the mean intakes were 48,71 , 95, 148, 195 and $241 \mathrm{mg} / \mathrm{kg}$ per d.

The measurements of $\mathrm{F}^{13} \mathrm{CO}_{2}$ from $\left[{ }^{13} \mathrm{C}\right]$ phenylalanine oxidation were made on two separate days with a $1 \mathrm{~d}$ interval. Three measurements at tyrosine intakes of 48, 71 and $95 \mathrm{mg} / \mathrm{kg}$ per $\mathrm{d}$ were performed on the first experimental day and, after a $1 \mathrm{~d}$ interval, measurements at tyrosine intakes of 148, 195 and $241 \mathrm{mg} / \mathrm{kg}$ per $\mathrm{d}$ were performed on the second experimental day. Each measurement was made during a $4 \mathrm{~h}$ period as shown in Fig. 1.

\section{Experimental diet}

Individual feeds were prepared for each subject and administered at the rate of $4.3 \mathrm{ml} / \mathrm{kg}$ per h during the isotope infusion protocol. At this rate it provided $627 \mathrm{~kJ}$ and $3.5 \mathrm{~g}$ protein $/ \mathrm{kg}$ per $\mathrm{d}$, with protein contributing $9.3 \%$ of total energy. The feed was prepared from Bionan milk powder (Nestlé SA, Vevey, Switzerland) and purified amino acids. Table 2 shows the composition of 1 litre of the experimental feed used to provide the lowest level of tyrosine $(47.6 \mathrm{mg} / \mathrm{kg}$ per d). Additional tyrosine was added in graded amounts $(0.185,0.37,0.74,1.11,1.48 \mathrm{~g})$ to provide the other five test levels of tyrosine. The $\mathrm{N}$ content of the feed was kept constant when the tyrosine intake was varied by adjusting the amount of glutamic acid (respectively, 4.36, 4.21, 3.91, 3.61, 3.31 g) added to the feed.

Choline, calcium lactate, glucose and maize oil were added to match the amount of these nutrients in an equivalent amount of Bionan. A stock solution $(32.13 \mathrm{mg}$ amino acids/g solution) of fourteen soluble amino acids (isoleucine, leucine, lysine, methionine, phenylalanine, threonine, tryptophan, valine, histidine, alanine, glycine, proline, serine and taurine) was prepared in water in the same proportions as present in Bionan milk and used to prepare the feed. The less soluble 


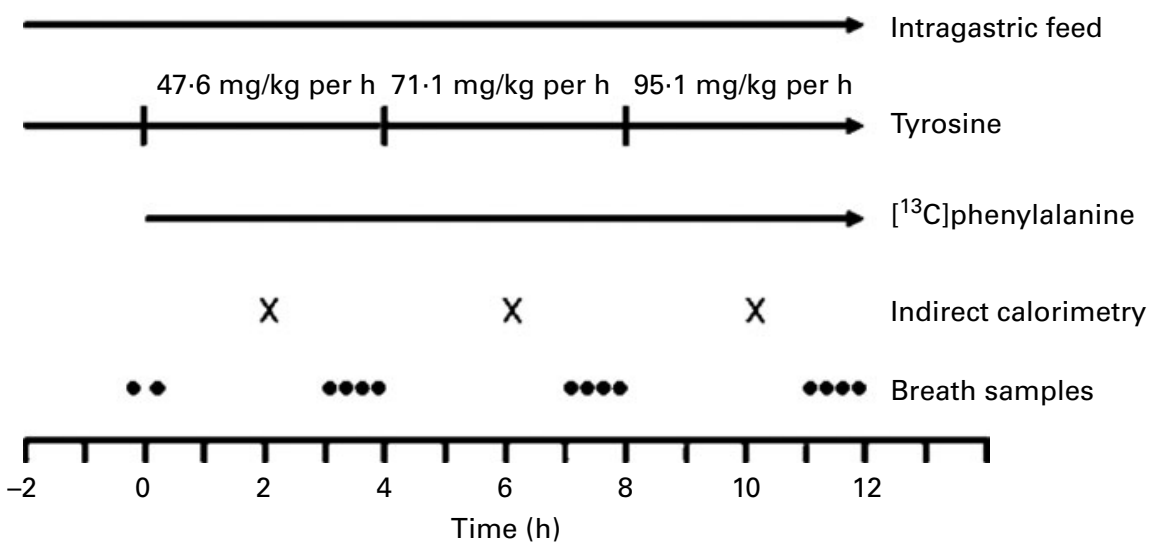

Fig. 1. Experimental protocol on day 1.

amino acids were added as individual solids. All ingredients were blended thoroughly. The amino acid composition of the $3.5 \mathrm{~g}$ protein $/ \mathrm{kg}$ per $\mathrm{d}$ administered to each child is shown in Table 3. The protein content was determined as the sum of the elemental amino acids and the protein content of the Bionan milk formula as stated on the label. The percentage of the total metabolisable dietary energy derived from protein, fat and carbohydrate was $9 \cdot 5,40 \cdot 1$ and 50.2, respectively. The diets were supplemented with vitamins (Tropivite; Federated Pharmaceuticals, Kingston, Jamaica), a mineral mix of $\mathrm{K}, \mathrm{Mg}$ and $\mathrm{Zn}$ salts $\left(37.28 \mathrm{~g} \mathrm{KCl}+50 \cdot 84 \mathrm{~g} \mathrm{MgCl}_{2} \cdot 6 \mathrm{H}_{2} \mathrm{O}\right.$ $+3.36 \mathrm{~g} \mathrm{Zn}\left(\mathrm{CH}_{3} \mathrm{COO}\right)_{2} \cdot 2 \mathrm{H}_{2} \mathrm{O}$ per litre water; Sigma, Atlanta, GA, USA) and iron sulfate $(60 \mathrm{mg} / \mathrm{d})$.

\section{Infusion protocol}

A diagram of the experimental protocol is shown in Fig. 1. An intravenous access site was established in an arm for infusion

Table 2. Composition of 1 litre of experimental feed

\begin{tabular}{|c|c|}
\hline Item & Content (per litre) \\
\hline Amino acid stock solution $(\mathrm{g})^{*}$ & $408 \cdot 7$ \\
\hline Aspartic acid (g) & 1.7 \\
\hline Arginine (g) & 0.6 \\
\hline Cystine (g) & 0.3 \\
\hline Tyrosine (g) & 0 \\
\hline Glutamic acid (g) & 4.5 \\
\hline Choline (g) & 0.1 \\
\hline Calcium lactate $(\mathrm{g})$ & 3.9 \\
\hline Glucose $(g)$ & 111 \\
\hline Bionan milk powder $(\mathrm{g}) \dagger$ & 62.5 \\
\hline Maize oil (g) & $37 \cdot 6$ \\
\hline Water $(\mathrm{g})$ & $369 \cdot 4$ \\
\hline Metabolisable energy (kJ) & 4935 \\
\hline Protein $(g)$ & $28 \cdot 1$ \\
\hline Fat $(\mathrm{g})$ & $52 \cdot 7$ \\
\hline Carbohydrate (g) & $148 \cdot 1$ \\
\hline \multicolumn{2}{|c|}{$\begin{array}{l}\text { *Contains } 32.13 \mathrm{mg} \text { amino acids } / \mathrm{g} \text { solution; } 3.01 \text { isoleucine, } 4.56 \\
\text { leucine, } 4.08 \text { lysine, } 1.18 \text { methionine, } 1.92 \text { phenylalanine, } 2.74 \\
\text { threonine, } 0.80 \text { tryptophan, } 3.07 \text { valine, } 1.07 \text { histidine, } 1.94 \\
\text { alanine, } 0.85 \text { glycine, } 3.9 \text { proline, } 2.86 \text { serine, } 0.15 \text { taurine. } \\
\text { † Contains } 1306.9 \mathrm{~kJ}, 7.8 \mathrm{~g} \text { protein, } 15.0 \mathrm{~g} \text { fat and } 36.8 \mathrm{~g} \text { carbohydrate } \\
\text { determined as stated by the manufacturer (Nestle SA, Vevey, } \\
\text { Switzerland) on the label. }\end{array}$} \\
\hline
\end{tabular}

of the $\left[{ }^{13} \mathrm{C}\right]$ phenylalanine by insertion of a $24 \mathrm{G}$ catheter after preparation of the access site with a topical anaesthetic (EMLA cream; Astra Pharmaceuticals Ltd, Kings Langley, Herts, UK). A small bore, soft nasogastric tube was inserted into the child's stomach and a Flexiflo Magna-Port Y-Port connector (Ross Products Division, Abbott Laboratories, Columbus, OH, USA) was attached to the proximal end. The experimental feed was then given over the next $14 \mathrm{~h}$ by continuous intragastric infusion at $4.32 \mathrm{ml} / \mathrm{kg}$ per $\mathrm{h}$ to deliver $58.3 \%$ of the child's estimated daily dietary intake of $627 \cdot 3 \mathrm{~kJ}$ and $3.5 \mathrm{~g}$ protein $/ \mathrm{kg}$ per $\mathrm{d}$.

Sterile solutions of $\left[{ }^{13} \mathrm{C}\right]$ phenylalanine and $\left[{ }^{13} \mathrm{C}\right]$ sodium bicarbonate (Cambridge Isotope Laboratories, Woburn, MA, USA) were prepared in $\mathrm{NaCl}(9 \mathrm{~g} / \mathrm{l})$. After $2 \mathrm{~h}$ of intragastric feeding, two breath samples were taken, a prime of $\left[{ }^{13} \mathrm{C}\right]$ sodium bicarbonate $(6 \mu \mathrm{mol} / \mathrm{kg})$ was given followed by a primed-constant infusion of $\left[{ }^{13} \mathrm{C}\right]$ phenylalanine (prime $=7$ $\mu \mathrm{mol} / \mathrm{kg}$, infusion $=7 \mu \mathrm{mol} / \mathrm{kg}$ per $\mathrm{h}$ ) for the next $12 \mathrm{~h}$ via the intragastric route. After every $4 \mathrm{~h}$, the feed was changed to increase the tyrosine intakes first to 71.1 and then to $95.1 \mathrm{mg} / \mathrm{kg}$ per $\mathrm{d}$ as shown in Fig. 1. Breath samples were collected at $20 \mathrm{~min}$ intervals from 3 to 4,7 to 8 and 11 to $12 \mathrm{~h}$ after the isotope infusion started. $\mathrm{CO}_{2}$ excretion rate was measured for $0.5 \mathrm{~h}$ in each of the three periods using a ventilated canopy system (Deltatrac 11 metabolic monitor; Sensormedics, Yorba Linda, CA, USA) while lying awake on a hospital bed. At the start of the project, an attempt was made to make more $\mathrm{CO}_{2}$ excretion rate measurements, but this was not tolerated well by the children. After a $1 \mathrm{~d}$ interval, the protocol was repeated at tyrosine intakes of 148, 195 and $242 \mathrm{mg} / \mathrm{kg}$ per $\mathrm{d}$.

\section{Sample analyses}

The breath samples were analysed in duplicate for ${ }^{13} \mathrm{C}$ abundance in $\mathrm{CO}_{2}$ by gas-isotope-ratio MS (Europa Scientific, Crewe, Cheshire, UK), monitoring ions at $\mathrm{m} / \mathrm{z}$ ratios 44 and 45. Plasma amino acids were isolated by ion exchange (Dowex 200x; Dow Chemical Co., Midland, MI, USA) chromatography, converted to the $n$-propyl ester, heptafluorobutyramide derivative and the isotopic enrichments of tyrosine measured by negative chemical ionisation GC-MS, selectively monitoring ions at $\mathrm{m} / \mathrm{z}$ ratios 595 to 596 . 
Table 3. Amino acid composition of the feed which provided $3.5 \mathrm{~g}$ protein $/ \mathrm{kg}$ per $\mathrm{d}$ and $47.3 \mathrm{mg}$ tyrosine $/ \mathrm{kg}$ per $\mathrm{d}$ during experimental period 1

\begin{tabular}{|c|c|c|c|}
\hline & Milk protein $(1 \mathrm{~g} / \mathrm{kg}$ per $\mathrm{d})$ & Amino acid mixture $(2.5 \mathrm{~g} / \mathrm{kg}$ per $\mathrm{d})$ & Total amino acids (mg/kg per $\mathrm{d}$ ) \\
\hline \multicolumn{4}{|c|}{ Soluble amino acids } \\
\hline Isoleucine & 63.0 & 157.5 & 220.5 \\
\hline Leucine & 95.5 & 238.75 & 334.2 \\
\hline Lysine & 85.4 & 213.5 & 298.9 \\
\hline Methionine & 24.7 & 61.75 & 86.4 \\
\hline Phenylalanine & $40 \cdot 1$ & $100 \cdot 25$ & $140 \cdot 3$ \\
\hline Threonine & 57.4 & 143.5 & $200 \cdot 9$ \\
\hline Tryptophan & $16 \cdot 8$ & $42 \cdot 0$ & $58 \cdot 8$ \\
\hline Valine & $64 \cdot 2$ & $160 \cdot 5$ & 224.7 \\
\hline Histidine & $22 \cdot 4$ & $56 \cdot 0$ & 78.4 \\
\hline Alanine & $40 \cdot 6$ & 101.5 & $142 \cdot 1$ \\
\hline Glycine & $17 \cdot 8$ & 44.5 & $62 \cdot 3$ \\
\hline Proline & $81 \cdot 7$ & $204 \cdot 25$ & 286.0 \\
\hline Serine & 59.9 & $149 \cdot 75$ & $209 \cdot 7$ \\
\hline Taurine & 3.2 & 8.0 & $11 \cdot 2$ \\
\hline \multicolumn{4}{|c|}{ Insoluble amino acids } \\
\hline Cystine & $15 \cdot 7$ & 39.25 & 54.9 \\
\hline Arginine & 29 & $72 \cdot 5$ & 101.5 \\
\hline Aspartic acid & $86 \cdot 9$ & $217 \cdot 25$ & 304.1 \\
\hline Tyrosine* & $47 \cdot 3$ & 0 & $47 \cdot 3$ \\
\hline Glutamic acid* & 192.5 & 577.35 & 769.9 \\
\hline
\end{tabular}

* In experimental periods 2 to 6 , the amount of tyrosine in the amino acid mixture was increased from 0 to $23.7,47.3,94.6,141.9$ and $189.2 \mathrm{mg} / \mathrm{kg}$ per d (for total intakes of $71.6,96.7,148.0,195.0$ and $242.0 \mathrm{mg} / \mathrm{kg}$ per d) and the glutamic acid was reduced to $558.1,538.9$, $500.5,462.0$ and $423.6 \mathrm{mg} / \mathrm{kg}$ per d.

\section{Calculations}

Tyrosine requirement was calculated from the relationship between its intake and $\mathrm{F}^{13} \mathrm{CO}_{2}$ during the $\left[{ }^{13} \mathrm{C}\right]$ phenylalanine infusion using the method described by Roberts et al. ${ }^{(7)}$. This method is based on the thesis that when dietary intake of phenylalanine is adequate but tyrosine intake is insufficient to meet metabolic demands and to maintain its pool, tyrosine derived from phenylalanine will be utilised primarily for anabolic purposes. In this situation tyrosine oxidation will be minimal, reflecting its obligatory oxidation. Hence $\mathrm{F}$ ${ }^{13} \mathrm{CO}_{2}$ from infused $\left[{ }^{13} \mathrm{C}\right]$ phenylalanine will be constant. When dietary tyrosine intakes are increased beyond requirement, however, the excess tyrosine will be oxidised to $\mathrm{CO}_{2}$. This will include both labelled and unlabelled tyrosine derived from phenylalanine. Hence, $\left[{ }^{13} \mathrm{C}\right]$ phenylalanine oxidation (via $\left[{ }^{13} \mathrm{C}\right]$ tyrosine) will increase proportionally and this will be reflected in a progressive increase in $\mathrm{F}{ }^{13} \mathrm{CO}_{2}$. This was confirmed by Roberts et al. ${ }^{(7)}$ who showed that both $\mathrm{F}$ ${ }^{13} \mathrm{CO}_{2}$ and phenylalanine oxidation were constant at lower intakes of tyrosine then increased linearly as tyrosine intakes increased beyond 66 and $82 \mathrm{mg} / \mathrm{kg}$ per d, respectively, in infants.

The $\mathrm{F}^{13} \mathrm{CO}_{2}$ data from two subjects were excluded from the analysis due to technical difficulties during the experiments. Tyrosine intakes and corresponding $\mathrm{F}^{13} \mathrm{CO}_{2}$ values for each subject are reported in Table 4. An estimate of the mean requirement was derived by breakpoint analysis with a twophase linear regression cross-over model using the mixed procedure of SAS software (version 9.2; SAS Institute Inc., Cary, NC, USA) with subject as a random effect ${ }^{(7,9)}$. This model allows the data points to be partitioned between two separate regression lines that minimise the residual error. The $\mathrm{F}^{13} \mathrm{CO}_{2}$ (dependent variable) values of each subject were partitioned to the tyrosine intakes of each subject with data points fitting either a flat line (zero slope) representing obligatory phenylalanine oxidation when tyrosine intakes are inadequate or an upward sloping line representing increased phenylalanine oxidation when tyrosine intakes are above requirement ${ }^{(7,9)}$. The breakpoint of the two linear regression lines was considered representative of the group mean tyrosine requirement.

${ }^{\mathrm{F}}{ }^{13} \mathrm{CO}_{2}$ was calculated from: $\mathrm{V} \mathrm{CO} \mathrm{CO}_{2} \times 44.6 \times \mathrm{E} \mathrm{CO}_{2}$, where $\mathrm{E} \mathrm{CO}_{2}$ is the enrichment of $\mathrm{CO}_{2}$ excreted in breath and the factor 44.6 converts $\mathrm{V} \mathrm{CO}_{2}$ from $\mathrm{ml} / \mathrm{kg}$ per min to $\mathrm{mmol} / \mathrm{kg}$ per min.

\section{Statistics}

Data are expressed as mean values with their standard errors. The paired $t$ test was used to compare clinical and physical

Table 4. Tyrosine intakes and corresponding ${ }^{13} \mathrm{C}$-labelled carbon dioxide excretion rates $\left(\mathrm{F}^{13} \mathrm{CO}_{2}\right)$ in individual subjects during experimental periods $1-6$

\begin{tabular}{lcc}
\hline Subject & $\begin{array}{c}\text { Tyrosine intakes } \\
(\mathrm{mg} / \mathrm{kg} \text { per } \mathrm{d})\end{array}$ & $\begin{array}{c}\mathrm{F}^{13} \mathrm{CO}_{2} \\
(\mu \mathrm{mol} / \mathrm{kg} \mathrm{per} \mathrm{min})\end{array}$ \\
\hline 1 & $47,70,93,162,216,270$ & $2 \cdot 98,3 \cdot 08,2 \cdot 86,3 \cdot 31,3 \cdot 94,4 \cdot 11$ \\
2 & $48,71,95,142,189,237$ & $2 \cdot 61,2 \cdot 62,2 \cdot 83,3 \cdot 04,3 \cdot 11,3 \cdot 43$ \\
3 & $47,71,95,142,189,236$ & $4 \cdot 96,5 \cdot 20,4 \cdot 98,5 \cdot 07,5 \cdot 20,6 \cdot 00$ \\
4 & $47,71,95,171,211,237$ & $4 \cdot 26,4 \cdot 49,4 \cdot 29,4 \cdot 33,5 \cdot 19,5 \cdot 21$ \\
5 & $47,71,94,142,189,237$ & $3 \cdot 94,3 \cdot 72,3 \cdot 82,3 \cdot 41,3 \cdot 56,4 \cdot 32$ \\
6 & $47,71,95,142,189,237$ & $3 \cdot 96,4 \cdot 30,4 \cdot 60,4 \cdot 62,4 \cdot 71,5 \cdot 15$ \\
7 & $48,76,101,152,203,253$ & $4 \cdot 51,4 \cdot 97,5 \cdot 46,5 \cdot 74,5 \cdot 97,5 \cdot 67$ \\
8 & $47,71,95,142,190,237$ & $2 \cdot 87,2 \cdot 20,2 \cdot 86,3 \cdot 11,3 \cdot 28,3 \cdot 22$ \\
9 & $47,71,94,142,190,237$ & $3 \cdot 66,3 \cdot 59,3 \cdot 90,4 \cdot 21,4 \cdot 32,4 \cdot 29$ \\
10 & $50,68,95,143,186,243$ & $3 \cdot 39,3 \cdot 20,3 \cdot 65,4 \cdot 09,4 \cdot 09,4 \cdot 09$ \\
11 & $47,71,95,151,188,235$ & $1 \cdot 47,1 \cdot 45,1 \cdot 87,2 \cdot 12,1 \cdot 94,2 \cdot 23$ \\
\hline
\end{tabular}


characteristics of the subjects at admission and at the time of their study. ANOVA was used to determine differences in $\mathrm{F}{ }^{13} \mathrm{CO}_{2}$ at different tyrosine intakes. Tests were considered statistically significant if $P<0 \cdot 05$. Data analysis was performed with SAS software (version 9.2; SAS Institute, Inc.).

\section{Results}

At the time that they participated in the study at about $19 \mathrm{~d}$ post-admission, the subjects were considered to be at about the mid-point of their rapid catch-up growth phase, as they were consuming about $627.3 \mathrm{~kJ}$ and about $3.5 \mathrm{~g}$ protein $/ \mathrm{kg}$ per $\mathrm{d}$ and gaining weight at $15 \mathrm{~g} / \mathrm{kg}$ per $\mathrm{d}$ (Table 1). At this time the subjects had lost all signs and symptoms of infection and those with kwashiorkor and marasmic kwashiorkor had lost their oedema. Compared with values at admission, the children's weights, weight-for-age, weight-for-length, $\mathrm{Hb}$ and albumin were significantly higher $(P<0.05)$, while body temperature was significantly lower $(P<0.05)$ (Table 1$)$.

The mean tyrosine intakes of the eleven subjects used in the analysis were 48, 71, 95, 148, 194 and $241 \mathrm{mg} / \mathrm{kg}$ per d. Enrichment measurement during the last $1 \mathrm{~h}$ in each $4 \mathrm{~h}$ period of $\left[{ }^{13} \mathrm{C}\right]$ phenylalanine infusion indicated that steady state was achieved for the ${ }^{13} \mathrm{CO}_{2}$ on breath. This was assessed by the absence of a significant slope. Fig. 2 shows the tracer:trace ratio of $\mathrm{CO}_{2}$ during the last $1 \mathrm{~h}$ of infusion. $\mathrm{F}$ ${ }^{13} \mathrm{CO}_{2}$ from phenylalanine oxidation remained unchanged between tyrosine intakes of 48 to $95 \mathrm{mg} / \mathrm{kg}$ per $\mathrm{d}$ and increased significantly from tyrosine intakes of 95 to
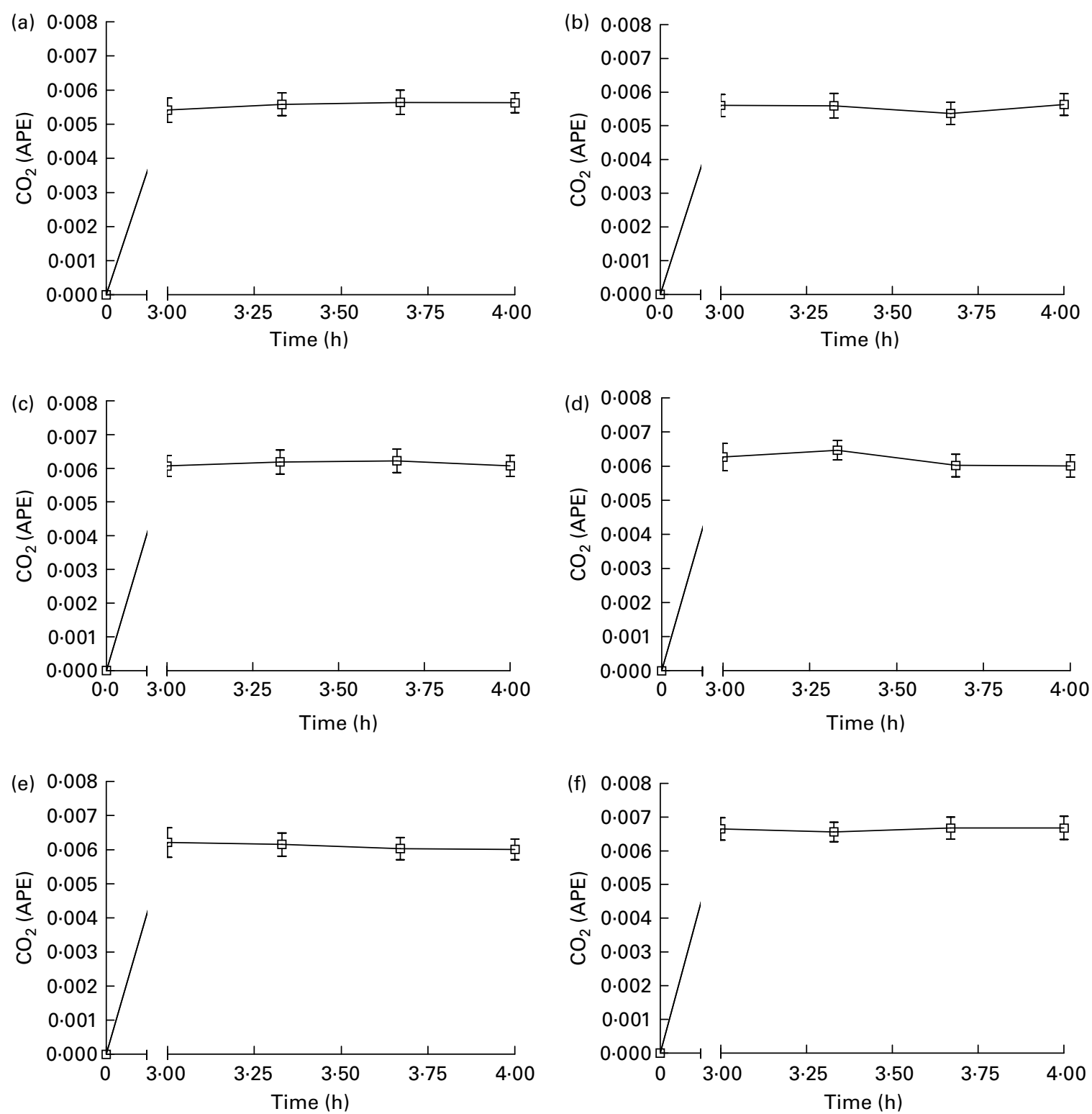

Fig. 2. Tracer:tracee ratio of breath $\mathrm{CO}_{2}$ (atoms percent excess; APE) showing steady-state enrichment during the fourth hour of $\left[{ }^{13} \mathrm{C}\right]$ phenylalanine infusion in the children on the six test levels of tyrosine intake: (a) $47.6 \mathrm{mg} / \mathrm{kg}$ per d; (b) $71.1 \mathrm{mg} / \mathrm{kg} \mathrm{per} \mathrm{d;} \mathrm{(c)} 95.1 \mathrm{mg} / \mathrm{kg} \mathrm{per} \mathrm{d;} \mathrm{(d)} 148 \mathrm{mg} / \mathrm{kg} \mathrm{per} \mathrm{d;} \mathrm{(e)} 195 \mathrm{mg} / \mathrm{kg} \mathrm{per} \mathrm{d;}$ (f) $241 \mathrm{mg} / \mathrm{kg}$ per $\mathrm{d}$. Values are means, with their standard errors represented by vertical bars. 


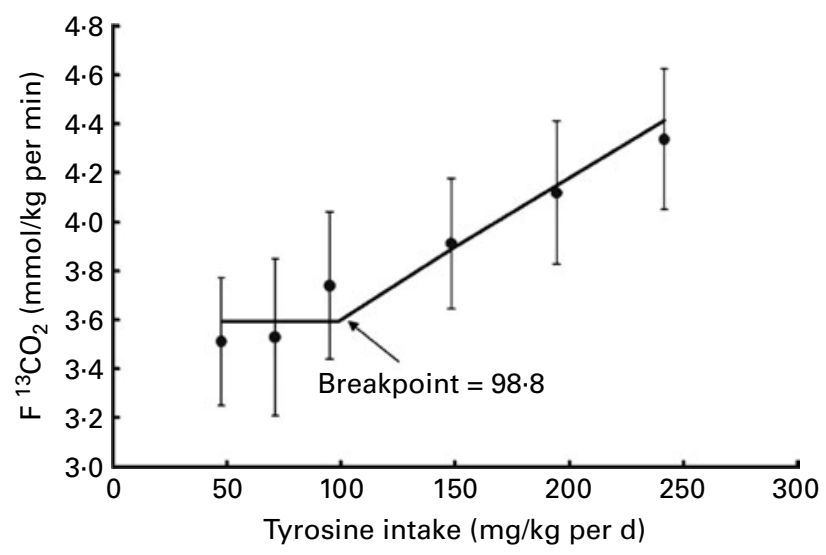

Fig. 3. Effect of tyrosine intake on the rate of excretion of ${ }^{13} \mathrm{CO}_{2}\left(\mathrm{~F}^{13} \mathrm{CO}_{2}\right)$ from $\left[{ }^{13} \mathrm{C}\right]$ phenylalanine oxidation in severely undernourished children during catch-up growth. Values are means at six tested tyrosine intake levels, from pooled data of all observation ( $n$ 66) and all subjects ( $n$ 11), with standard errors represented by vertical bars. The intersection of the two regression lines (breakpoint) represents the mean tyrosine requirement of $98.8 \mathrm{mg} / \mathrm{kg}$ per $\mathrm{d}$.

$241 \mathrm{mg} / \mathrm{kg}$ per d $(P<0 \cdot 01)$. Based on our model, three $\mathrm{F}^{13} \mathrm{CO}_{2}$ data points corresponding to tyrosine intakes of 48,71 and $95 \mathrm{mg} / \mathrm{kg}$ per $\mathrm{d}$ fitted a flat line with a zero slope and the other three fitted an upward-sloping line $\left(r^{2} 0 \cdot 99\right)$. The breakpoint, i.e. the point of intersection of the two lines, occurred between tyrosine intakes of 95 and $148 \mathrm{mg} / \mathrm{kg}$ per $\mathrm{d}$ at a value of $99 \mathrm{mg} / \mathrm{kg}$ per d (Fig. 3). This value represents an estimate of the mean tyrosine requirement of children with SCU during their rapid catch-up growth phase.

\section{Discussion}

In the present study we aimed to determine the tyrosine requirement of severely undernourished children during the rapid catch-up growth phase of treatment. In our current rehabilitation feeding protocol, the amount of food, hence energy and protein, consumed by the children during the rapid catch-up growth phase is based on their appetite. Usual intakes range from 418.2 to $752.8 \mathrm{~kJ}$ and 2.3 to $4.2 \mathrm{~g}$ protein $/ \mathrm{kg}$ per $\mathrm{d}$. Tyrosine requirement was measured when the children's daily intakes had reached about $627.3 \mathrm{~kJ}$ and $3.5 \mathrm{~g}$ protein $/ \mathrm{kg}$ per $\mathrm{d}$, i.e. about the mid-point of their catch-up growth period. Based on the amino acid composition of Bionan milk protein (1 whey: 1 casein), the children were consuming $165.5 \mathrm{mg}$ tyrosine $/ \mathrm{kg}$ per $\mathrm{d}$ at this time. The two-phase linear regression cross-over model used to analyse our data gives an estimate of mean tyrosine requirement of about $99 \mathrm{mg} / \mathrm{kg}$ per $\mathrm{d}$, which is about $40 \%$ less than the amount that was being consumed by the children at this phase of their recovery from SCU. Hence, the energy-dense rehabilitation diet traditionally used in the TMRU ward during the rapid catch-up growth phase of treatment seems to provide a more than adequate amount of tyrosine to the children.

It is possible that there is a difference in tyrosine requirement between the male and female children because sex might contribute to variation in the demand for protein and amino acids ${ }^{(10)}$. However, further studies are required to assess such an effect which is, also, not quantified in normal healthy children ${ }^{(10)}$. One advantage of the method that we used over the traditional $\mathrm{N}$ balance technique is the finding of Zello et al..$^{(11)}$ that prior adaptation to the test amino acids is not needed. On this basis, we assume that there is no significant carry-over effect from one level of tyrosine to another. For at least $2 \mathrm{~d}$ before the isotopic measurements, the children were fed protein and energy at the same rate as for the study period to allow for adaptation to the level of protein intake as recommended by Thorpe et al. ${ }^{(12)}$. However, a limitation of the method is that the feeds with different levels of tyrosine were not given in random order. It is, also, assumed that the measurement of $\mathrm{CO}_{2}$ excretion rates for only $0.5 \mathrm{~h}$ is representative of the $4 \mathrm{~h}$ duration for each level of tyrosine tested. At the start of the investigation, an attempt was made to make more measurements during the test periods, but the children became fussy and uncomfortable.

It is important to point out that the rate and extent of catchup growth will vary depending on the degree of wasting and stunting as well as according to the density of energy and nutrients of the food provided or available ${ }^{(10)}$. For these reasons, our estimate of tyrosine requirement cannot be generalised to all conditions of catch-up growth. In the present study, the estimation of tyrosine requirement is mainly associated with restoring weight-for-height because peak velocity for catch-up in height growth commences after restoration of weight-for-height ${ }^{(13)}$. Also, because the requirement of an amino acid is predominantly for maintenance of protein synthesis and other metabolic pathways, and for new lean tissue deposition, the need for tyrosine during catch-up growth will be different with variation in rate of growth and extent of lean tissue deposition. There is evidence for variation in the rate and composition of weight gained depending to a large extent on differences in dietary energy and protein content ${ }^{(14-16)}$. Moreover, when Spady et al. ${ }^{(17)}$ used a single high-energy diet for catch-up growth, they reported that weight gain measured between days 7 and 14 varied from 3.2 to $21.5 \mathrm{~g} / \mathrm{kg}$ per $\mathrm{d}$. Therefore, although we used a typical catch-up growth diet enriched in energy and nutrients, the estimated value for tyrosine requirement derived in the present study is conditional on the composition of the treatment diet used, rate of weight gain and amount of lean tissue deposited in the children. Lean tissue deposition, which was not measured in the present study, can be limited by the protein: energy ratio of the $\operatorname{diet}^{(10,15,16)}$. It has been estimated that at high rates of catch-up growth $(10-20 \mathrm{~g} / \mathrm{kg}$ per d), a high rate of fat deposition is expected with a protein:energy ratio up to $0 \cdot 07$, and normal composition of weight gain is expected with a ratio up to $0 \cdot 15^{(16)}$. In the present study, protein contributed $9.3 \%$ of dietary energy and the children were growing at a fast rate of about $15 \mathrm{~g} / \mathrm{kg}$ per $\mathrm{d}$.

Although we did not measure lean tissue deposition, based on our previous measurement of body composition measurement during catch-up growth in children using the same rehabilitation diet, if we assume that $80 \%$ of the new tissue is fat-free mass ${ }^{(18)}$ of which about $20 \%$ is protein, then it can be estimated that the children were depositing about $2.4 \mathrm{~g}$ protein $/ \mathrm{kg}$ per $\mathrm{d}$. With a protein intake of $3.5 \mathrm{~g} / \mathrm{kg}$ per $\mathrm{d}$, this translates to an efficiency of utilisation of $69 \%$, which is in close agreement with the value of about $66 \%$ calculated from the $\mathrm{N}$ balance data reported by us in a previous study of severely undernourished children during the catch-up growth phase $\mathrm{e}^{(14)}$. Assuming that tyrosine is 
$2.55 \%$ of human whole-body protein ${ }^{(13)}$, then it can be calculated that $61.2 \mathrm{mg}$ tyrosine $/ \mathrm{kg}$ per d, i.e. $62 \%$ of estimated requirement, was being utilised to synthesise new body proteins for the net accumulation of lean tissue. If we were to assume that the phenylalanine intake, which was fixed at $140 \mathrm{mg} / \mathrm{kg}$ per d, was a fair estimate of the children's requirement at this time, then the ratio of phenylalanine to tyrosine requirements of SCU children during catch-up growth will be 59:41, which is similar to the 55:45 ratio of these two amino acids in body tissue ${ }^{(19)}$. Also, this is close to the phenylalanine to tyrosine requirements ratios reported by Roberts et al $^{(7,20)}$ for neonates $(56: 44)$ and adult males (60:40).

Although tyrosine is considered a nutritionally dispensable amino acid, because it can be synthesised de novo, there is a high demand for this amino acid as a precursor molecule for the synthesis of numerous proteins, peptides and metabolites, more so during the accelerated protein deposition of the catchup growth phase. Our finding suggests that the children were consuming a more than adequate amount of protein to satisfy their tyrosine requirements at this phase of treatment. We now plan to conduct a similar study to estimate the phenylalanine requirement of children with SCU during the catch-up growth phase of recovery using a diet that will provide tyrosine based on its requirement as estimated in the present study.

\section{Acknowledgements}

We are grateful to the physicians and nursing staff of the TMRU for their care of the children and to Lorraine Wilson, Bentley Chambers, Margaret Frazer, Melanie Del Rosario and Megan Frelich for their excellent work and support in the conduct of the studies and analysis of the samples. This research was supported by National Institutes of Health (NIH) grant 1RO1 DK 075018, and with federal funds from the US Department of Agriculture, Agricultural Research Service under Cooperative Agreement no. 58-6250-6001.

A. B. and F. J. contributed to the design of the study, execution of the experiments, data collection, analysis and interpretation, and writing of the manuscript. M. R. and T. F. were involved in the design and execution of the study. J. W.-C. H. was responsible for statistical analysis and contributed to interpretation of the data. C. T.-B. was the paediatrician responsible for clinical management of the patients and participated in the execution of the study.

None of the authors had any personal or financial conflict of interest.

\section{References}

1. Gibson N, Jahoor F, Ware L, et al. (2002) Endogenous glycine and tyrosine production is maintained in adults on a marginal protein diet. Am J Clin Nutr 75, 511-518.

2. Jahoor F, Badaloo A, Reid M, et al. (2005) Protein kinetic differences between children with edematous and nonedematous protein-energy malnutrition in the fed and postabsorptive states. Am J Clin Nutr 82, 792-800.
3. Fjeld CR, Schoeller DA \& Brown KH (1989) Body composition of children recovering from severe proteinenergy malnutrition at two rates of catch-up growth. Am J Clin Nutr 50, 1266-1275.

4. Jackson AA (1990) Protein requirements for catch-up growth. Proc Nutr Soc 49, 507-516.

5. World Health Organization (1999) Management of Severe Malnutrition: A Manual for Physicians and Other Senior Health Workers. Geneva: WHO.

6. Reeds PJ, Fjeld CR \& Jahoor F (1994) Do the differences between the amino acid compositions of acute-phase and muscle proteins have a bearing on nitrogen loss in traumatic states? J Nutr 124, 906-910.

7. Roberts SA, Ball RO, Moore AM, et al. (2001) The effect of graded intake of glycyl-L-tyrosine on phenylalanine and tyrosine metabolism in parenterally fed neonates with an estimation of tyrosine requirement. Pediatr Res 49, 111-119.

8. Wellcome Working Party (1970) Classification of infantile malnutrition. Lancet ii, 302-303.

9. Littell RC, Milliken GA, Stroup WW, et al. (2006) Analysis of repeated measures data. In SAS System for Mixed Models, pp. 159-204. Cary, NC: SAS Institute, Inc.

10. World Health Organization (2007) Catch-up growth. In Protein and Amino Acids Requirements in Human Nutrition. Report of a Joint WHO/FAO/UNU Expert Consultation. WHO Technical Report Series no. 935, pp. 185-193. Geneva: WHO.

11. Zello GA, Pencharz PB \& Ball RO (1990) Phenylalanine flux, oxidation, and conversion to tyrosine in humans studied with L- $\left[1-{ }^{13}\right.$ C]phenylalanine. Am J Physiol 259, E835-E843.

12. Thorpe JM, Roberts SA, Ball RO, et al. (1999) Prior protein intake may affect phenylalanine kinetics measured in healthy adult volunteers consuming $1 \mathrm{~g}$ protein $\cdot \mathrm{kg}^{-1} \cdot \mathrm{d}^{-1} . J$ Nutr 129, 343-348.

13. Waterlow JC (1992) Protein Energy Malnutrition, 1st ed. London: Edward Arnold.

14. Badaloo A, Boyne M, Reid M, et al. (1999) Dietary protein, growth and urea kinetics in severely malnourished children and during recovery. J Nutr 129, 969-979.

15. Jackson AA \& Wootton SA (1990) The energy requirements of growth and catch-up growth. In Activity, Energy Expenditure and Energy Requirements of Infants and Children, pp. 185-214 [B Schurch and NS Scrimshaw, editors]. Lausanne, Switzerland: IDECG.

16. Dewey KG, Beaton G, Fjeld C, et al. (1996) Protein requirements in infants and children. Eur J Clin Nutr 50, Suppl., S119-S147.

17. Spady DM, Payne PR, Picou D, et al. (1976) Energy balance during recovery from malnutrition. Am J Clin Nutr 29, 1073-1088.

18. Reid M, Forrester T, Badaloo A, et al. (2004) Supplementation with aromatic amino acids improves leucine kinetics but not aromatic amino acid kinetics in infants with infection, severe malnutrition, and edema. J Nutr 134, 3004-3010.

19. Block RJ \& Weiss KW (1956) Amino Acid Handbook. Methods and Results of Protein Analysis. Springfield, IL: Charles C. Thomas.

20. Roberts SA, Thorpe JM, Ball RO, et al. (2001) Tyrosine requirement of healthy men receiving a fixed phenylalanine intake determined by using indicator amino acid oxidation. Am J Clin Nutr 73, 276-282. 